\title{
Does frailty predict postoperative outcomes in geriatric patients receiving surgery for colorectal cancer? A systematic review and meta-analysis
}

\section{XIAOBO YANG ( $\sim$ paulayeung@link.cuhk.edu.hk)}

Shanghai Jiao Tong University Medical School Affiliated Ruijin Hospital https://orcid.org/0000-00033107-5892

\section{Chenying Xu}

Shanghai Jiao Tong University Medical School Affiliated Ruijin Hospital

\section{Jiumei Cao}

Shanghai Jiao Tong University Medical School Affiliated Ruijin Hospital

\section{Li Xie}

Shanghai Jiao Tong University School of Medicine

\section{Qingqing Qiu}

Shanghai Jiao Tong University Medical School Affiliated Ruijin Hospital, Luwan Branch

\section{Jiaan Hu}

Shanghai Jiao Tong University Medical School Affiliated Ruijin Hospital

\section{Lifen Yu}

Shanghai Jiao Tong University Medical School Affiliated Ruijin Hospital

\section{Jean Woo}

Chinese University of Hong Kong

\section{Research article}

Keywords: Frailty, colorectal cancer, surgery, postoperative complication, mortality

Posted Date: June 19th, 2020

DOl: https://doi.org/10.21203/rs.3.rs-32419/v1

License: (c) (1) This work is licensed under a Creative Commons Attribution 4.0 International License.

Read Full License 


\section{Abstract}

Background Surgery remains the mainstay of colorectal cancer (CRC) and substantially reduces cancerrelated morbidity and mortality. Preoperative assessment for frailty in geriatric patients is critically important in risk stratification and clinical decision-making. In this systematic review and meta-analysis, we aimed to quantitatively summarise the effect of frailty on postoperative outcomes in geriatric patients receiving surgery for CRC. Methods A systematic literature search was conducted in MEDLINE, Cochrane and EMBASE from inception to 30 April 2020. Fully published articles reporting risk estimate(s) of frailty on postoperative complication(s), readmission and/ or mortality in patients aged $\geq 65$ years who received surgery for CRC were eligible for qualitative and quantitative analyses. Results Across 10 articles of 9 unique studies $(n=69332)$ that were eventually included in the systematic review and meta-analysis, overall prevalence of frailty was $23.0 \%$ (95\% Cl: $11-43 \%, \mathrm{I} 2=100 \%)$. Odds ratios (ORs) on overall and severe postoperative complications were respectively increased by $2.36-(95 \% \mathrm{Cl}: 1.66-3.35, \mathrm{P}<0.01 ; \mathrm{I} 2=$ $12 \%$ ) and 2.35 -fold ( $95 \% \mathrm{Cl}: 1.30-4.27, \mathrm{P}<0.01 ; \mathrm{I} 2=72 \%)$ in frail patients compared to non-frail counterparts. On pooled analysis, frailty was significantly associated with an increased risk of postoperative readmission (OR:1.91; $95 \% \mathrm{Cl}: 1.35-2.70, \mathrm{P}<0.01 ; \mathrm{I} 2=6 \%$ ). Whilst a significantly higher risk of frailty on mortality during 12 months after CRC surgery was observed (OR: 5.52; 95\% Cl:4.40-6.92, $\mathrm{P}<0.01 ; \mathrm{I} 2=89 \%$ ), the summary OR on 30-day/ inpatient mortality crossed the null line (OR: $1.65 ; 95 \% \mathrm{Cl}$ : $0.56-4.93, P=0.37 ;$ I $2=55 \%)$. Funnel plot and Duval-Tweedie's trim and fill test did not reveal significant publication bias. Conclusions In the studies reviewed, frailty appeared to be associated with increased risks for postoperative complications, readmission and mortality during 12 months in patients aged $\geq 65$ years who received surgery for CRC. Nevertheless, no significant association between frailty and 30-day/ inpatient postoperative mortality was observed.

\section{Background}

In 2012, approximately 700,000 deaths from colorectal cancer (CRC) were recorded, making CRC the fourth leading cause of cancer death worldwide [1]. The incidence of CRC dramatically rises up to 1.8 million new cases annually due to a rapidly ageing population, shift in dietary patterns and reduction in physical activity [2]. The risk of CRC increases sharply with age. Individuals aged $>60$ years have an over 50-time higher risk of CRC compared to those younger than 40 years, contributing to $80 \%$ of cases diagnosed [3]. Comprehensive geriatric assessment is currently regarded as the gold standard to globally evaluate older adults' health status; however this assessment may not be feasible due to time constraints and lack of expertise. Screening for frailty is more practicable in routine clinical practice [4]. Given that surgery remains the mainstay of $\mathrm{CRC}$ and effectively decreases distant metastasis, local recurrence and cancer-related mortality, accurate evaluation on general health status and identification of frailty preoperatively is of great importance in clinical decision-making [5]. Previously a meta-analysis has demonstrated comorbidity is associated with higher risks of overall and cancer-specific mortality [6]. However, the impact on postoperative outcomes in elderly patients with CRC has never been quantitatively examined by using formal frailty assessment instrument(s) [7]. Also, the underlying 
mechanisms by which frailty confer a poorer prognosis need to be determined yet [8-10]. In this systematic review and meta-analysis, we aimed to summarize current evidence and quantitatively evaluate the effect of frailty on postoperative outcomes in geriatric patients receiving surgery for CRC.

\section{Methods}

\section{Research question and eligibility criteria for literature search}

The systematic review and meta-analysis was conducted following the Preferred Reporting Items for Systematic Reviews and Meta-analyses (PRISMA) guidelines and the Meta-Analysis of observational studies in Epidemiology (MOOSE) guidelines [11, 12] (PRISMA checklist available in Additional file 1: Table S1). The study focused on the following research question: Does frailty predict clinical outcomes in patients who received surgery for CRC? Studies were included in the systematic review and meta-analysis when they met the following criteria: 1) Patients received surgery for CRC either for curative or palliative purpose; 2) Patients were aged 65 years or above; 3) Studies were conducted as case-control, cohort or nested design; 4) Formal frailty assessment instruments were utilized and assessed preoperatively; 5) Risk estimates on clinical outcomes including postoperative complication(s), readmission and/or mortality compared between frail and non-frail patients were expressed as either hazard ratio (HR) or odds ratio (OR); 6) Studies were published as full articles; 7) Studies were conducted in human population; 7) Articles were published in English. Studies were excluded if 1) Patients with CRC did not receive surgical therapy; 2) No formal frailty assessment was available in the articles; 3 ) Risk estimates compared between frail and non-frail patients were unavailable in the articles; 4) Studies were published as conference abstracts; 5) Studies were conducted in animals; 6) Articles were written in language(s) other than English.

\section{Search strategy}

Literature search through MEDLINE, Cochrane and EMBASE databases was systematically performed from inception to $30 \mathrm{Apr} 2020$ to identify studies that compared the risk estimates on clinical outcomes between frail and non-frail patients who received surgery for CRC. The following key Medical Subject Headings (MeSH) terms were used for literature search: 'frailty' OR 'frail' AND 'colorectal carcinoma' OR 'colorectal cancer' OR 'colorectal malignancy' OR 'bowel surgery' OR 'colectomy' OR 'colorectomy' OR 'colon resection' OR 'colorectal resection'. The identified records were independently scanned and assessed by two research investigators (XY \& CX) to identify the eligible studies. Discrepancies between the two researchers were discussed and resolved by two senior researchers (JW \& LY).

\section{Data extraction}

Information on study population, study design, frailty assessment instruments, prevalence rate of frailty, comorbidities, the American Society of Anesthesiologists Physical classification System (ASA classification), prevalence rates of postoperative complications, length of in-hospital stay, risk estimates on clinical outcomes including, postoperative complication(s) and mortality was extracted from the 
eligible studies. The severity of complications was graded according to predefined criteria $[13,14]$. When necessary, corresponding authors of the publications were contacted for either clarification of data redundancy or data recalculation for associated risk estimates.

\section{Assessment of publication bias}

Quality of study assessment was conducted using Newcastle-Ottawa Scale (NOS) for cohort studies for assessing risk of bias by two researchers $(X Y \& C X)$ independently [15]. High-quality studies were graded when 7 or above out of 9 points were obtained using NOS. Discrepancies between the two authors were resolved by two senior researchers (JW \& LY).

\section{Statistical analysis}

Meta-analyses were conducted using the inverse of variance method and random-effects models by assuming that the true value of the effect size of each study is sampled from a probability distribution rather than identical. Data from the same study and population were calculated only once based on the most recent available publication and/ or the largest sample size to avoid data redundancy $[16,17]$. Forest plots were used to present the pooled estimates in graphical form. $P$ values lower than 0.05 were regarded as statistically significant. Low heterogeneity was defined by using the Cochrane $Q$ test with $<25 \%$ of $P^{2}$, while moderate and high heterogeneity were defined as $<50 \%$ and $\geq 50 \%$, respectively [18]. Egger's linear regression, Begg's rank correlation test and leave-one-out sensitivity analysis were further conducted to identify potential reason(s) for high heterogeneity (i.e. $P^{2} \geq 50 \%$ ) $[19,20]$.

Risk estimates from the models that adjusted for the maximum numbers of covariates were selected for data-analysis, where alternative adjusted estimates were available. When multivariate risk estimate was unavailable, univariate risk estimate was used instead. Indirect methods of extracting estimates were used, where risk effect was not directly reported in the publication $[16,21,22]$. The OR and $95 \%$ confidence interval $(\mathrm{Cl})$ were calculated. Funnel plot and Duval-Tweedie's trim and fill test were used to visually ad quantitatively assess publication bias. Statistical analyses were performed by Review Manager Version 5.3 (Cochrane IMS, Copenhagen, Denmark) and R Version 4.0.0 (R Foundation for statistical Computing).

\section{Results}

\section{Study selection}

The initial search identified 2035 records, of which 1035, 165 and 835 were collected from MEDLINE, Cochrane and EMBASE, respectively (Figure 1). After 2025 records were excluded due to duplicates, reviews, conference abstracts and irrelevant contents, 10 articles of 9 unique studies were eventually included in the systematic review and meta-analysis. 
A total of 69332 patients (males: 50.9\% (35240/69249) reported in 9 unique studies) who received surgery for CRC were eventually included in the systematic review and meta-analysis (Table 1). Seven articles of 6 studies $[16,17,22-26]$ presented a prospective observational design reporting longitudinal data, while data from the remaining 3 studies were retrospectively analyzed [8, 21, 27]. Study characteristics including population, study design, sample size frailty assessment instrument and risk estimates were summarized in Table 1.

Frailty assessment instruments and prevalence rate of frailty in patients receiving CRC surgery

The overall prevalence of frailty derived from 9 unique studies was $26 \%(95 \% \mathrm{Cl}: 16-38 \%, P=99 \%)$ (Table 2 \& Figure 2A), whereas seven studies focusing on elective surgery showed a slightly lower pooled prevalence of frailty as $25 \%\left(95 \% \mathrm{Cl}: 14-41 \%, P^{2}=100 \%\right.$ ) (Figure $\left.2 \mathrm{~B}\right)$. Notably, patients receiving elective operation accounted for $99.8 \%(68673 / 68750)$ as indicated in original studies (Table 1$)$.

Impact of frailty on postoperative clinical outcomes

\section{Postoperative complications}

Six studies $[17,21,22,24,26,27]$ reported overall postoperative complications in comparison between frail and non-frail patients (Table 2). Forest plot showed that frailty was associated with an increased risk of postoperative complications (OR: $2.36,95 \% \mathrm{Cl}$ : 1.66-3.35, $P<0.01 ; P^{2}=12 \%$ ) (Figure $3 \mathrm{~A}$ ). Similar result was observed in patients who underwent elective surgery (OR: $2.50,95 \% \mathrm{Cl}: 1.72-3.63, P<0.01 ; P^{2}=15 \%$ ) $[17,21,24,26]$ (Figure 3B). The pooled risk estimate of being frail on severe complications was increased by 2.35 -fold ( $95 \% \mathrm{Cl}$ : $1.30-4.27, P<0.01 ; P^{2}=72 \%$ ) compared to that of being non-frail $[17,23,27]$ (Figure 3C). Subanalysis on elective surgery was summarized in 2 studies [17, 23], also revealing a significant association between frailty and severe complications (OR: $3.25 ; 95 \% \mathrm{Cl}: 2.00-5.28, P<0.01 ; P^{2}=0$ ) (Figure 3D). However, the summary risk of frailty on postoperative anastomotic leakage summarized in 4 studies was statistically non-significant (OR: 1.84 (95\% Cl: 0.98-3.46, P>0.05, $P=0$ ) [17, 22-24] (Figure 3E).

\section{Postoperative readmission}

A total of 3 studies $[17,24,27]$ reported risk estimate of frailty on postoperative readmission (Table 2), indicating an overall OR value of $1.91\left(95 \% \mathrm{Cl}\right.$ : $\left.1.35-2.70, R^{2}=6 \%\right)$ (Figure 4$)$.

\section{Postoperative mortality}

A significant higher risk of frailty on mortality during 12 months after CRC surgery was observed in 5 studies (OR: 5.52; 95\% Cl: $4.40-6.92, P<0.01)$, with a high heterogeneity identified $\left(I^{2}=89\right)$ (Table 2 \& Figure $5 A$ ). A subanalysis on elective surgery also revealed a significant association (OR: $5.66 ; 95 \% \mathrm{Cl}$ : $4.51-7.11, P<0.01 ; P^{2}=89 \%$ ) (Figure $5 \mathrm{~B}$ ). While the summary OR on 30-day/ inpatient mortality crossed the null line (OR: $1.65 ; 95 \% \mathrm{Cl}$ : $0.56-4.93, P=0.37 ; I^{2}=55 \%$ ) (Figure 5 C), a 2.01 -fold increased risk of 
frailty was identified in subanalysis on elective surgery (OR: $2.01 ; 95 \% \mathrm{Cl}: 1.25-3.22, P<0.01 ; P^{2}=56 \%$ ) (Figure 5D)

Two studies $[16,25]$ reported time-effect of frailty on mortality, suggesting frailty was associated with 3.33-fold increased HR of long-term mortality ( $95 \% \mathrm{Cl}$ : 2.21-5.01, $P<0.01 ; P^{2}=0 \%$ ) (Table 2 \& Figure 5E).

\section{Study quality and Publication bias}

Assessment of study quality yielded the 10 articles were all scored $\geq 7$ out of 9 points using NOS (Additional file 1: Table S2). On estimating prevalence of frailty, $66.7 \%(6 / 9)$ of the included studies fell outside the $95 \% \mathrm{Cl}$ of funnel plot control limits. We therefore proceeded to performing trim and fill test and found publication bias was trivial (adjusted prevalence of frailty: $34.3 \%$; $95 \% \mathrm{Cl}$ : 20.58-51.27, P $<0.01 ; P^{2}=99.8 \%$ ) (Additional file 1: Figure S1). Egger's linear regression or Begg's rank correlation test did not reveal strong evidence of publication bias in prevalence of frailty (Egger's test: $P=0.431$; Begg's test: $P=0.532)$.

Funnel plot, Egger's or Begg's test was not performed in the forest plot for pooled risk estimate of frailty on severe complications, 30-day/ inpatient or 1-year mortality due to small number of studies. When leave-one-out sensitivity analysis was performed, the overall prevalence of frailty did not significantly differ, indicating an acceptable robustness of pooled estimate (Additional file 1: Table S3). Nevertheless, the heterogeneity identified in OR of frailty on severe postoperative complications, 30-day/ inpatient mortality and mortality within one year was significantly diminished by the leave-one-out approach (Additional file 1: Tables S4-S6).

\section{Discussion}

Impact of frailty on postoperative outcomes in patients receiving surgery for CRC

To our knowledge, this study was first to systematically synthesize quantitative evidence and evaluate the effects of frailty on postoperative outcomes in patients who received surgery for CRC. The results showed that frailty negatively impacted postoperative complications by $\sim 2.35$-fold. Slightly higher ORs were observed in patients receiving elective surgery. Moreover, frailty was associated with 1.91- and 6.16fold increased risks of postoperative readmission and mortality during 12 months, whereas the effect of frailty on 30-day/ inpatient mortality reached statistical significance in patients who underwent elective surgery only.

Studies previously reported frailty was an independent factor in predicting postoperative complications, readmission and mortality in abdominal and cardiothoracic surgeries in older adults [28,29]. Because aggressive treatment (e.g. curative surgery) contributes to dysregulation of systemic immune system, causing progressive organ damage and exacerbating decline in physiological reserve [21], identifying frail patients in elderly population is essentially crucial in decision-making and therapeutic options. Moreover, postoperative outcome(s) leading to prolonged inpatient stay incurs substantial additional costs of 
medical care, and at the same time leading to poorer quality of life and increased risk of emergency readmission [30].

Several mechanisms potentially explain the association between frailty and postoperative adverse outcomes in patients undergoing surgery for CRC. First, frailty characterised by vulnerability and impaired physiological preserve is accompanied by up-regulation of inflammatory and proinflammatory cytokines (e.g. interleukin (IL)-6, C-reaction protein (CRP), tumour necrosis factor (TNF)-a, etc.), leading to the development of systemic inflammatory response [31]. This positive association between inflammatory markers and postoperative complications are particularly evident in occurrence of sepsis, anastomotic leakage and pulmonary insufficiency [32].

Second, frailty is frequently accompanied by the coexistence of multi-morbidity, being more frequent with increasing degrees of frailty [33]. However, while preoperative comorbidities and ASA classification are widely accepted as perioperative risk stratification tools and associated with higher risks of complications and mortality [34], the predictive value of frailty assessment instruments in conjunction with co-morbidity or perioperative complications on mortality is still limited in literature [35].

Third, increased risks of anemia, hypoalbuminemia and poor nutritional status associated with frailty have been well documented [36-38]. Condition of being anemic or malnourished directly prolonged postoperative recovery due to surgical complications (e.g. dehiscence, anastomotic leakage, surgical site infection, etc.) in colorectal and other major abdominal surgeries [39-41]. Nevertheless, the risk estimate on major surgical complications(s) such as anastomotic leakage and/or abscess formation crossed the line of null effects summarized from 4 studies in this study. There are many factors thought to affect anastomotic leakage following colorectal surgery. Evidence has showed general factors (e.g. advanced age, obesity, malnutrition, corticosteroid use, etc.), local factors (e.g. vascular flow insufficiency, infection, etc.) as well as technical and experience factors (e.g. tumour location, operative modalities (i.e. laparoscopic $v s$. open surgery), anastomotic tension, etc.) all influence the integrity of conduit and anastomotic healing $[39,42,43]$. Subanalyses on tumour site, operation modality, etc. were not performed in this study due to data insufficiency. The association between frailty and postoperative anastomotic leakage is yet to be investigated in future studies.

Fourth, reduction in muscle mass and mitochondrial enzyme activity exacerbated by curative operation in turn activates muscle inflammation and predisposes to frailty process [44]. Although pre-habilitation training effectively reduced morbidity and mortality after intra-abdominal cancer surgery [45], its role in improving postoperative muscle strength and functional capacity is yet to be determined. Furthermore, the degree of frailty severity fluctuating over time is rarely reported in CRC patients.

Fifth, altered composition of commensal microbiota, if present, potentiates the development of frailty and bowel oncogenicity $[46,47]$. Although causal evidence showing interlinks between changes in gut microbial communities, frailty process and CRC formation is scarce, long-term alteration in gut microbiota after colorectal surgery may disturb skeletal muscle protein synthesis, resulting in muscle atrophy and attenuation [48]. 
Frailty generally affects $12.8 \%$ of older individuals aged $\geq 60$ years and is more prevalent in cancer patients [49-51]. In this systematic review and meta-analysis, we reported that preoperative prevalence rate of frailty in CRC patients aged $\geq 65$ years was $26.0 \%$ (95\% Cl: $16-38 \%$ ranging from $4.4-52.2 \%$ ) in 9 unique studies, with a very high level of heterogeneity identified. While dozens of frailty assessment instruments are used worldwide [52], no standard frailty index is specifically validated for CRC patients in predicting postoperative prognosis. Pandit et colleagues [21] recently proposed a modified frailty index (Colon Cancer Frailty Index (CCFI) in conjunction of previously validated Canadian Study of Health and Aging Frailty Index (CSHA-FI) and two additional variables (i.e. anemia and weight loss), guiding the strategy on treatment options and complications [21, 53].

Another indicator of frailty is the cumulative deficit index, using clinical and/or laboratory variables and expressing the index as the number of abnormal variables over the total number of variables tested [54]. The predictive value of this index in evaluating complications and mortality reached $\sim 0.70$ after gastrointestinal tract surgery [55]. However, this index is more readily available for large-scale epidemiological data than in routine clinical practice. In contrast, magnitude of impairment of physiological reserve by objective/ semi-objective measures (i.e. muscle strength, gait speed, energy expenditure, etc.) is assessed in the Fried frailty phenotype. In this meta-analysis, only one study used Fried frailty phenotype [56]. More frequently, other frailty assessment instruments (e.g. Groningen Frailty Index (GFI), the John Hopkins' Adjusted Clinical Groups (ACG) definition of frailty, etc.) with multidimensional aspects (i.e. physical, functional and psychosocial domains) are currently used in CRC researches, in line with recommendations of the International Society of Geriatric Oncology (SIOG) suggesting that geriatric assessment (GA) incorporated with some initial screening tools (e.g. G8, VES-13, etc.) be assessed in CRC patients with $\geq 65$ years of age who are candidates for surgical procedures [57], given that increasing age coupled with coexisting medical conditions and psychosocial issues makes therapeutic decision(s) more challenging.

\section{Limitations of the study}

There are several limitations in this systematic review and meta-analysis.

First, distribution of curative and palliative purpose that was only available in three of the included studies made it unable to in particular analyze the effect of frailty on mortality and other outcomes across the subgroups. Among patients with metastatic CRC, majority of the lesions are unresectable, despite that a few of them can still be amenable to curative resection of primary tumour and metastases. Palliative surgery is mainly reserved for these patients, which confers an operative mortality rate at 6$10 \%$ [58] and postoperative morbidity between 18-47\% [59]. However, some of the studies reported that no significant association was observed between tumour stage and postoperative complication(s) [17]. Moreover, in multivariable analysis, frailty status remained to be an independent prognostic indicator after adjustment for TNM stage [16]. Second, only all-cause mortality was considered as a hard endpoint in this study. Non-cancer-specific mortality has been the main form of competing risk that occurs and 
leads to biased results when applying survival analysis [60]. Competing risk nomograms has been established for gastrointestinal cancer diseases in the recent years in order that overall survival (OS) and cancer-specific survival (CSS) in patients with surgically resected tumours can be predicted [61, 62]. As far as we know, only two studies previously explored discrimination between physiologically fit and nonfit patients in cancer-related and non-cancer specific mortality after curative resection for CRC [63, 64]. However, neither of them predicted outcomes by utilizing formal frailty assessment instrument(s). Competing risk models including functional and nutritional factors will be critical in classifying geriatric patients according to their frailty status [63].Third, as an important confounder affecting prognosis, emergency surgery was not absolutely eliminated in this study, although we attempted to subanalyze the patients who underwent elective surgery. The positive correlation between emergent surgical presentation and postoperative mortality in elderly patients undergoing CRC surgery was confirmed in previous studies $[65,66]$. Given that an emergent surgical presentation in a senior patient frequently points at a diagnosis of bowel obstruction or perforation, these two conditions often indicate an advanced stage and carry a poor prognosis [65]. Also, it is unlikely that preoperative assessment and prehabilitation training can be implemented in these patients. Fourth, frailty assessment instruments were not uniformly assessed. Some studies mostly relied on physical components, while others used multidimensional approach, culminating in large variance in prevalence of frailty. Moreover, risk estimates were extracted directly or calculated indirectly from relatively small numbers of studies. Furthermore, univariate risk estimates were used in some of the studies when multivariate appraisals were unavailable in original publications.

\section{Conclusions}

Frailty is highly prevalent in geriatric patients receiving surgery for CRC. In the studies reviewed, frailty appeared to be associated with higher risks of postoperative complications, readmission and mortality during 12 months. Nevertheless, no significant association between frailty and 30-day/ inpatient postoperative mortality was observed.

\section{Abbreviations}

CRC: colorectal cancer; Cl: confidence interval; OR: odds ratio; PRISMA: Preferred Reporting Items for Systematic Reviews and Meta-analyses; MOOSE: the Meta-Analysis of observational studies in Epidemiology; HR: hazard ratio; MeSH: Medical Subject Headings; ASA: the American Society of Anesthesiologists; NOS: Newcastle-Ottawa Scale; NS: non-significant; LOS: length of stay; ISAR-HP: identification of Seniors at Risk for Hospitalised Patients; IL: interleukin; CRP: C-reaction protein; TNF: tumour necrosis factor; CCFI: Colorectal Cancer Frailty Index; CSHA-FI: Canadian Study of Health and Aging Frailty Index; GFI: Groningen Frailty Index; SIOG: the International Society of Geriatric Oncology; GA: geriatric assessment; OS: overall survival; CSS: cancer-specific survival.

\section{Declarations}

\section{Ethics approval and consent to participate}


Not declared.

\section{Consent for publication}

Not applicable.

\section{Availability of data and materials}

The datasets analyzed in the study are available from the corresponding author upon reasonable request.

\section{Competing interests}

The authors declare they have no competing interests.

\section{Funding}

The study was supported by grants from Shanghai Municipal

Commission of Health and Family Planning for Key Discipline Establishment (2015ZB0503) and the Hong Kong Jockey Club and the Research Grants Council. The funding body had no role in the study design; data collection, analysis and interpretation; manuscript writing and revision; or decision to publish.

\section{Authors' contributions}

$X Y, L Y, J W$ participated in study concepts and design. XY, CX, LY and JW performed the literature search, data extraction and quality assessment. $X Y, C X, L X$ and QQ ran the statistical tests. $X Y$ and JW were the major contributors of the manuscript writing. CX, JC, LX, QQ, JH, LY participated in manuscript revision. All the authors read and approved the final manuscript.

\section{Acknowledgements}

Not applicable.

\section{Authors' information}

${ }^{1}$ Department of Geriatrics, Ruijin Hospital, Shanghai Jiao Tong University School of Medicine, Shanghai, 200025 China. ${ }^{2}$ Department of Medicine and Therapeutics, Faculty of Medicine, The Chinese University of Hong Kong, Hong Kong SAR. ${ }^{3}$ Clinical Research Institute, Shanghai Jiao Tong University School of Medicine, Shanghai, 200025 China. ${ }^{4}$ Department of Surgery, Ruijin Hospital Luwan Branch, Shanghai Jiao Tong University School of Medicine, Shanghai, 200025 China. ${ }^{5}$ Department of Gastroenterology, Ruijin Hospital, Shanghai Jiao Tong University School of Medicine, Shanghai, 200025 China. ${ }^{6} \mathrm{CUHK}$ Jockey Club Institute of Ageing, The Chinese University of Hong Kong, Hong Kong SAR. 


\section{References}

1. Arnold M, Sierra MS, Laversanne M, Soerjomataram I, Jemal A, Bray F: Global patterns and trends in colorectal cancer incidence and mortality. Gut 2017, 66(4):683-691.

2. WHO: International Agency for Research on Cancer. Latest global cancer data: cancer burden rises to 18.1 million new cases and 9.6 million cancer deaths in 2018. Avaiable at: https://www.who.int/cancer/en/ (Accessed: 12 December 2018).

3. Cancer Research UK: Bowel cancer statistics. Available at: https://www.cancerresearchuk.org/healthprofessional/cancer-statistics/statistics-by-cancer-type/bowel-cancer - heading-Zero (Accessed: 2016).

4. Dent E, Morley JE, Cruz-Jentoft AJ, Woodhouse L, Rodríguez-Mañas L, Fried LP, Woo J, Aprahamian I, Sanford A, Lundy J et al: Physical Frailty: ICFSR International Clinical Practice Guidelines for Identification and Management. The journal of nutrition, health \& aging 2019, 23(9):771-787.

5. Saxton A, Velanovich V: Preoperative frailty and quality of life as predictors of postoperative complications. Ann Surg 2011, 253(6):1223-1229.

6. Boakye D, Rillmann B, Walter V, Jansen L, Hoffmeister M, Brenner H: Impact of comorbidity and frailty on prognosis in colorectal cancer patients: A systematic review and meta-analysis. Cancer Treat Rev 2018, 64:30-39.

7. Fagard K, Leonard S, Deschodt M, Devriendt E, Wolthuis A, Prenen H, Flamaing J, Milisen K, Wildiers $\mathrm{H}$, Kenis $\mathrm{C}$ : The impact of frailty on postoperative outcomes in individuals aged 65 and over undergoing elective surgery for colorectal cancer: A systematic review. J Geriatr Oncol 2016, 7(6):479-491.

8. Neuman HB, Weiss JM, Leverson G, O'Connor ES, Greenblatt DY, Loconte NK, Greenberg CC, Smith MA: Predictors of short-term postoperative survival after elective colectomy in colon cancer patients $>/=\mathbf{8 0}$ years of age. Ann Surg Oncol 2013, 20(5):1427-1435.

9. Heldens AFJM, Bongers BC, Lenssen AF, Stassen LPS, Buhre WF, van Meeteren NLU: The association between performance parameters of physical fitness and postoperative outcomes in patients undergoing colorectal surgery: An evaluation of care data. Eur J Surg Onco/ 2017, 43(11):2084-2092.

10. Agasi-Idenburg SC, Punt CJA, Aaronson NK, Stuiver MM: The association between preoperative fatigue and instrumental activities in daily living with complications and length of hospital stay in patients undergoing colorectal surgery. Aging Clin Exp Res 2019.

11. Stroup DF, Berlin JA, Morton SC, Olkin I, Williamson GD, Rennie D, Moher D, Becker BJ, Sipe TA, Thacker SB: Meta-analysis of observational studies in epidemiology: a proposal for reporting. Metaanalysis Of Observational Studies in Epidemiology (MOOSE) group. JAMA 2000, 283(15):2008-2012.

12. Shamseer L, Moher D, Clarke M, Ghersi D, Liberati A, Petticrew M, Shekelle P, Stewart LA, Group. P-P: Preferred reporting items for systematic review and meta-analysis protocols (PRISMA-P) 2015: elaboration and explanation. BMJ 2015, 250:g7647. 
13. Dindo D, Demartines N, Clavien P: Classification of Surgical Complications. Annals of Surgery 2004, 240(2):205-213.

14. Clavien PA, Sanabria JR, Strasberg SM: Proposed classification of complications of surgery with examples of utility in cholecystectomy. Surgery 1992, 111(5):518-526.

15. Stang A: Critical evaluation of the Newcastle-Ottawa scale for the assessment of the quality of nonrandomized studies in meta-analyses. Eur J Epidemiol 2010, 25(9):603-605.

16. Ommundsen N, Wyller TB, Nesbakken A, Jordhøy MS, Bakka A, Skovlund E, Rostoft S: Frailty is an independent predictor of survival in older patients with colorectal cancer. Oncologist 2014, 19(12):1268-1275.

17. Kristjansson SR, Nesbakken A, Jordhøy MS, Skovlund E, Audisio RA, Johannessen HO, Bakka A, Wyller TB: Comprehensive geriatric assessment can predict complications in elderly patients after elective surgery for colorectal cancer: a prospective observational cohort study. Crit Rev Oncol Hematol 2010, 76(3):208-217.

18. Higgins JP, Thompson SG, Deeks JJ, Altman DG: Measuring inconsistency in meta-analyses. $B M J$ 2003, 327(7414):557-560.

19. Begg CB, Mazumdar M: Operating characteristics of a rank correlation test for publication bias. $B M J$ 1994, 50(4):1088-1101.

20. Egger M, Davey Smith G, Schneider M, Minder C: Bias in meta-analysis detected by a simple, graphical test. $B M J$ 1997, 315(7109):629-634.

21. Pandit V, Khan M, Martinez C, Jehan F, Zeeshan M, Koblinski J, Hamidi M, Omesieta P, Osuchukwu O, Nfonsam $\mathrm{V}$ : A modified frailty index predicts adverse outcomes among patients with colon cancer undergoing surgical intervention. Am J Surg 2018, 216(6):1090-1094.

22. Reisinger KW, van Vugt JL, Tegels JJ, Snijders C, Hulsewé KW, Hoofwijk AG, Stoot JH, Von Meyenfeldt MF, Beets GL, Derikx JP et al: Functional compromise reflected by sarcopenia, frailty, and nutritional depletion predicts adverse postoperative outcome after colorectal cancer surgery. Ann Surg 2015, 261(2):345-352.

23. Okabe H, Ohsaki T, Ogawa K, Ozaki N, Hayashi H, Akahoshi S, Ikuta Y, Ogata K, Baba H, Takamori H: Frailty predicts severe postoperative complications after elective colorectal surgery. Am J Surg 2019, 217(4):677-681.

24. Souwer ETD, Verweij NM, van den Bos F, Bastiaannet E, Slangen RME, Steup WH, Hamaker ME, Portielje JEA: Risk stratification for surgical outcomes in older colorectal cancer patients using ISARHP and G8 screening tools. J Geriatr Oncol 2018, 9(2):110-114.

25. Ugolini G, Pasini F, Ghignone F, Zattoni D, Bacchi Reggiani ML, Parlanti D, Montroni I: How to select elderly colorectal cancer patients for surgery: a pilot study in an Italian academic medical center. Cancer Biol Med 2015, 12(4):302-307.

26. Tan KY, Kawamura YJ, Tokomitsu A, Tang T: Assessment for frailty is useful for predicting morbidity in elderly patients undergoing colorectal cancer resection whose comorbidities are already optimized. Am J Surg 2012, 204(2):139-143. 
27. Gearhart SL, Do EM, Owodunni O, Gabre-Kidan AA, Magnuson T: Loss of Independence in Older Patients after Operation for Colorectal Cancer. J Am Coll Surg 2020, 230(4):573-582.

28. Kim SW, Han HS, Jung HW, Kim KI, Hwang DW, Kang SB, Kim CH: Multidimensional frailty score for the prediction of postoperative mortality risk. JAMA Surg 2014, 149(7):633-640.

29. Han B, Li Q, Chen X: Frailty and postoperative complications in older Chinese adults undergoing major thoracic and abdominal surgery. Clin Interv Aging 2019, 14:947-957.

30. Shida D, Wakamatsu K, Tanaka Y, Yoshimura A, Kawaguchi M, Miyamoto S, Tagawa K: The postoperative patient-reported quality of recovery in colorectal cancer patients under enhanced recovery after surgery using QoR-40. BMC Cancer 2015, 15:799.

31. Clegg A, Young J, Iliffe S, Rikkert MO, Rockwood K: Frailty in elderly people. The Lancet 2013, 381(9868):752-762.

32. Rettig TC, Verwijmeren L, Dijkstra IM, Boerma D, van de Garde EM, Noordzij PG: Postoperative Interleukin-6 Level and Early Detection of Complications After Elective Major Abdominal Surgery. Ann Surg 2016, 263(6):1207-1212.

33. Theou O, Rockwood MR, Mitnitski A, Rockwood K: Disability and co-morbidity in relation to frailty: how much do they overlap? Arch Gerontol Geriatr 2012, 55(2):e1-8.

34. Dekker JW, Gooiker GA, van der Geest LG, Kolfschoten NE, Struikmans H, Putter H, Wouters MW, Tollenaar RA: Use of different comorbidity scores for risk-adjustment in the evaluation of quality of colorectal cancer surgery: does it matter? Eur J Surg Oncol 2012, 38(11):1071-1078.

35. Bateni SB, Bold RJ, Meyers FJ, Canter DJ, Canter RJ: Comparison of common risk stratification indices to predict outcomes among stage IV cancer patients with bowel obstruction undergoing surgery. J Surg Oncol 2018, 117(3):479-487.

36. Röhrig G: Anemia in the frail, elderly patient. Clin Interv Aging 2016, 11:319-326.

37. Lorenzo-López L, Maseda A, de Labra C, Regueiro-Folgueira L, Rodríguez-Villamil JL, Millán-Calenti JC: Nutritional determinants of frailty in older adults: A systematic review. BMC Geriatr 2017, 17(1):108.

38. Smit E, Winters-Stone KM, Loprinzi PD, Tang AM, Crespo CJ: Lower nutritional status and higher food insufficiency in frail older US adults. Br J Nutr 2013, 110(1):172-178.

39. Kirchhoff P, Clavien PA, Hahnloser D: Complications in colorectal surgery: risk factors and preventive strategies. Patient Saf Surg 2010, 4(1):5.

40. Bootsma BT, Huisman DE, Plat VD, Schoonmade LJ, Stens J, Hubens G, van der Peet DL, Daams F: Towards optimal intraoperative conditions in esophageal surgery: A review of literature for the prevention of esophageal anastomotic leakage. Int J Surg 2018, 54(Pt A):113-123.

41. Li Y, Tan B, Fan L, Zhao Q, Tan M, Wang D, Jia N, Liu Q: Clinicopathologic Characteristics of Elderly with Gastric Cancer, and the Risk Factors of Postoperative Complications. J Invest Surg 2017, 30(6):394-400. 
42. Ban KA, Gibbons MM, Ko CY, Wick EC: Surgical Technical Evidence Review for Colorectal Surgery Conducted for the AHRQ Safety Program for Improving Surgical Care and Recovery. J Am Coll Surg 2017, 225(4):548-557.

43. Chida K, Watanabe J, Suwa Y, Suwa H, Momiyama M, Ishibe A, Ota M, Kunisaki C, Endo I: Risk factors for incisional surgical site infection after elective laparoscopic colorectal surgery. Ann Gastroenterol Surg 2019, 3(2):202-208.

44. Phillips BE, Smith K, Liptrot S, Atherton PJ, Varadhan K, Rennie MJ, Larvin M, Lund JN, Williams JP: Effect of colon cancer and surgical resection on skeletal muscle mitochondrial enzyme activity in colon cancer patients: a pilot study. J Cachexia Sarcopenia Muscle 2013, 4(1):71-77.

45. Heger P, Probst P, Wiskemann J, Steindorf K, Diener MK, Mihaljevic AL: A Systematic Review and Meta-analysis of Physical Exercise Prehabilitation in Major Abdominal Surgery (PROSPERO 2017 CRD42017080366). J Gastrointest Surg 2019.

46. Zapata HJ, Quagliarello VJ: The microbiota and microbiome in aging: potential implications in health and age-related diseases. J Am Geriatr Soc 2015, 63(4):776-781.

47. Bultman SJ: Interplay between diet, gut microbiota, epigenetic events, and colorectal cancer. Mol Nutr Food Res 2017, 61(1).

48. Lin XH, Jiang JK, Luo JC, Lin CC, Ting PH, Yang UC, Lan YT, Huang YH, Hou MC, Lee FY: The long term microbiota and metabolic status in patients with colorectal cancer after curative colon surgery. PLoS One 2019, 14(6):e0218436.

49. Ofori-Asenso R, Lee Chin K, Mazidi M, Zomer E, Ilomaki J, Ademi Z, Bell JS, Liew D: Natural Regression of Frailty Among Community-Dwelling Older Adults: A Systematic Review and MetaAnalysis. Gerontologist 2019, May 22([Epub ahead of print]).

50. Williams GR, Deal AM, Muss HB, Weinberg MS, Sanoff HK, Guerard EJ, Nyrop KA, Pergolotti M, Shachar SS: Frailty and skeletal muscle in older adults with cancer. J Geriatr Oncol 2018, 9(1):68-73.

51. Bréchemier D, Sourdet S, Girard P, Steinmeyer Z, Mourey L, Gérard S, Balardy L: Use of comprehensive geriatric assessment (CGA) to define frailty in geriatric oncology: Searching for the best threshold. Cross-sectional study of $\mathbf{4 1 8}$ old patients with cancer evaluated in the geriatric frailty clinic (G.F.C.) of Toulouse (France). J Geriatr Oncol 2019, pii: S1879-4068(18):30471-30475.

52. Buta BJ, Walston JD, Godino JG, Park M, Kalyani RR, Xue QL, Bandeen-Roche K, Varadhan R: Frailty assessment instruments: Systematic characterization of the uses and contexts of highly-cited instruments. Ageing Res Rev 2016, 26:53-61.

53. Leichtle SW, Mouawad NJ, Lampman R, Singal B, Cleary RK: Does preoperative anemia adversely affect colon and rectal surgery outcomes. J Am Coll Surg 2011, 212(2):187-194.

54. Mitnitski AB, Mogilner AJ, Rockwood K: Accumulation of deficits as a proxy measure of aging. ScientificWorld Journal 2001, 1:323-323.

55. Giannotti C, Sambuceti S, Signori A, Ballestrero A, Murialdo R, Romairone E, Scabini S, Caffa I, Odetti $P$, Nencioni A et al: Frailty assessment in elective gastrointestinal oncogeriatric surgery: Predictors of one-year mortality and functional status. J Geriatr Oncol 2019. 
56. Fried LP, Tangen CM, Walston J, Newman AB, Hirsch C, Gottdiener J, Seeman T, Tracy R, Kop WJ, Burke G et al: Frailty in Older Adults: Evidence for a Phenotype. J Gerontol A Biol Sci Med Sci 2001, 56(3):M146-M156.

57. Papamichael D, Audisio RA, Glimelius B, de Gramont A, Glynne-Jones R, Haller D, Kohne CH, Rostoft $\mathrm{S}$, Lemmens $\mathrm{V}$, Mitry $\mathrm{E}$ et al: Treatment of colorectal cancer in older patients: International Society of Geriatric Oncology (SIOG) consensus recommendations 2013. Ann Oncol 2015, 26(3):463-476.

58. Gonzalez R, Smith CD, Ritter EM, Mason E, Duncan T, Ramshaw BJ: Laparoscopic palliative surgery for complicated colorectal cancer. Surg Endosc 2005, 19(1):63-46.

59. Su Q, Yao L, Zhang J, Du G, Xu B: In Situ Transmission Electron Microscopy Observation of the Lithiation-Delithiation Conversion Behavior of CuO/Graphene Anode. ACS App/ Mater Interfaces 2015, 7(41):23062-23068.

60. Berry SD, Ngo L, Samelson EJ, Kiel DP: Competing risk of death: an important consideration in studies of older adults. J Am Geriatr Soc 2010, 58(4):783-787.

61. Wang Z, Wang Y, Yang Y, Luo Y, Liu J, Xu Y, Liu X: A competing-risk nomogram to predict causespecific death in elderly patients with colorectal cancer after surgery (especially for colon cancer). World J Surg Oncol 2020, 18(1):30.

62. Wang SB, Qi WX, Chen JY, Xu C, Kirova YM, Cao WG, Cai R, Cao L, Yan M, Cai G: Competing risk nomogram predicting initial loco-regional recurrence in gastric cancer patients after D2 gastrectomy. Radiat Oncol 2019, 14(1):128.

63. Antonio M, Saldaña J, Carmona-Bayonas A, Navarro V, Tebé C, Nadal M, Formiga F, Salazar R, Borràs JM: Geriatric Assessment Predicts Survival and Competing Mortality in Elderly Patients with Early Colorectal Cancer: Can It Help in Adjuvant Therapy Decision-Making? Oncologist 2017, 22(8):934943.

64. Richards $\mathrm{CH}$, Leitch EF, Horgan PG, Anderson JH, McKee RF, McMillan DC: The relationship between patient physiology, the systemic inflammatory response and survival in patients undergoing curative resection of colorectal cancer. Br J Cancer 2010, 103(9):1356-1361.

65. Novello M, Mandarino FV, Di Saverio S, Gori D, Lugaresi M, Duchi A, Argento F, Cavallari G, Wheeler JN, B.: Post-operative outcomes and predictors of mortality after colorectal cancer surgery in the very elderly patients. Heliyon 2019, 5(8):e02363.

66. van Eeghen EE, den Boer FC, Loffeld RJ: Thirty days post-operative mortality after surgery for colorectal cancer: a descriptive study. J Gastrointest Oncol2015, 6(6):613-617.

\section{Tables}

Table 1 Characteristics of the included studies. 


\begin{tabular}{|c|c|c|c|c|c|c|c|c|c|c|}
\hline $\begin{array}{l}\text { Duration of } \\
\text { recruitment }\end{array}$ & Study design & $\begin{array}{l}\text { Sample } \\
\text { size }\end{array}$ & Age (y) & $\begin{array}{l}\text { Male } \\
\text { gender } \\
(n, \%)\end{array}$ & $\begin{array}{l}\text { ASA } \\
\text { classification }\end{array}$ & $\begin{array}{l}\text { Open } \\
\text { surgery } \\
(n, \%)\end{array}$ & $\begin{array}{l}\text { Purpose } \\
\text { of } \\
\text { surgery }\end{array}$ & $\begin{array}{l}\text { Categories } \\
\text { for surgery }\end{array}$ & $\begin{array}{l}\text { Sites of } \\
\text { CRC }\end{array}$ & Stage of CRC \\
\hline $\begin{array}{l}\text { Jan 2016- } \\
\text { Dec } 2018\end{array}$ & Retrospective & 1676 & $75(69-81)$ & $\begin{array}{l}841 \\
50.2 \%\end{array}$ & $\begin{array}{l}\text { I-II: } 23.6 \% \\
\text { III-IV: } 76.4 \%\end{array}$ & $\begin{array}{l}618 \\
36.9 \%\end{array}$ & $\mathrm{~N} / \mathrm{A}$ & $\begin{array}{l}\text { Both } \\
\text { elective } \\
\text { and non- } \\
\text { elective; } \\
\text { elective } \\
\text { percentage: } \\
79.3 \% \\
(1329 / 1676)\end{array}$ & N/A & $\begin{array}{l}\text { Disseminated } \\
\text { cancer: } 9.5 \%\end{array}$ \\
\hline $\begin{array}{l}\text { Jan 2011- } \\
\text { Aug } 2016\end{array}$ & $\begin{array}{l}\text { Prospective, } \\
\text { observational }\end{array}$ & 269 & $\begin{array}{l}\text { Frail: } 80 \text { (65- } \\
89) ; \\
\text { Non-frail: } 68 \\
(65-84)\end{array}$ & $\begin{array}{l}167 \\
62.1 \%\end{array}$ & N/A & $\begin{array}{l}99, \\
36.8 \%\end{array}$ & Curative & Elective & N/A & $\begin{array}{l}\text { Stage I-II: } \\
70.6 \% \\
\text { Stage III-IV: } \\
29.4 \%\end{array}$ \\
\hline 2011 & Retrospective & 53652 & $\begin{array}{l}\text { Frail: } 75.2 \pm 8.1 \\
\text { Non-frail: } \\
75.1 \pm 7.3\end{array}$ & $\begin{array}{l}28898 \\
53.9 \%\end{array}$ & N/A & $\begin{array}{l}22288 \\
41.5 \%\end{array}$ & N/A & Elective & N/A & N/A \\
\hline $\begin{array}{l}\text { May 2015- } \\
\text { Aug } 2016\end{array}$ & $\begin{array}{l}\text { Prospective, } \\
\text { observational }\end{array}$ & 139 & $77.7(75.0-82.8)$ & $\begin{array}{l}76 \\
55 \%\end{array}$ & $\begin{array}{l}\text { I-II: } 71 \% ; \\
\text { III-V: } 29 \% \\
-\end{array}$ & $\begin{array}{l}33 \\
24 \%\end{array}$ & Curative & Elective & $\begin{array}{l}\text { Colon: } \\
82 \% ; \\
\text { Rectum: } \\
18 \%\end{array}$ & $\begin{array}{lr}\text { Stage I: } & 24 \% \text {; } \\
\text { Stage } & \text { II: } \\
41 \% ; & \\
\text { Stage } & \text { III: } \\
35 \% . & \end{array}$ \\
\hline $\begin{array}{l}\text { Sep 2009- } \\
\text { Jun } 2012\end{array}$ & $\begin{array}{l}\text { Prospective, } \\
\text { observational }\end{array}$ & 46 & $80.52 \pm 6.68$ & $\begin{array}{l}24 \\
52.2 \%\end{array}$ & N/A & $\begin{array}{l}24 \\
52.2 \%\end{array}$ & N/A & Elective & N/A & N/A \\
\hline $\begin{array}{l}\text { Nov 2006- } \\
\text { Jun } 2008\end{array}$ & $\begin{array}{l}\text { Prospective, } \\
\text { observational }\end{array}$ & 178 & $\begin{array}{l}70-79 \text { Y: } 89 \\
50 \% \\
80-89 \text { Y: } 79 \\
44 \% \\
\geq 90 \text { Y: } 10,6 \%\end{array}$ & $\begin{array}{l}76 \\
43 \%\end{array}$ & N/A & $\begin{array}{l}118 \\
66 \%\end{array}$ & N/A & Elective & $\begin{array}{l}\text { Colon: } \\
71 \% ; \\
\text { Rectum: } \\
29 \%\end{array}$ & $\begin{array}{l}\text { TNM stage } \\
0: 5 \% \\
\text { I: } 24 \% \text {; } \\
\text { II: } 32 \% \text {; } \\
\text { III: } 25 \% \text {; } \\
\text { IV: } 12 \% \text {; } \\
\text { Unclassified: } \\
2 \%\end{array}$ \\
\hline $\begin{array}{l}\text { Jan 2010- } \\
\text { May } 2012\end{array}$ & $\begin{array}{l}\text { Prospective, } \\
\text { observational }\end{array}$ & $\begin{array}{l}310 \text { (of } \\
\text { whom } \\
\text { GFI } \\
\text { score } \\
\text { was } \\
\text { assessed } \\
\text { in } 153 \\
\text { patients) }\end{array}$ & N/A & $\begin{array}{l}155 \\
50 \%\end{array}$ & $\begin{array}{l}\text { I: } 5.5 \% \text {; } \\
\text { II: } 70.6 \% \text {; } \\
\text { III: } 20.0 \% \text {; } \\
\text { IV: } 3.9 \%\end{array}$ & $\begin{array}{l}277 \\
89.4 \%\end{array}$ & N/A & $\begin{array}{l}\text { Both } \\
\text { elective } \\
\text { and acute }\end{array}$ & $\begin{array}{l}\text { Colon: } \\
66.1 \% \text {; } \\
\text { Rectum: } \\
33.9 \% .\end{array}$ & N/A \\
\hline 1999-2005 & Retrospective & 12979 & $84.4 \pm 3.7$ & $\begin{array}{l}5003 \\
39 \%\end{array}$ & $\mathrm{~N} / \mathrm{A}$ & N/A & Curative & Elective & N/A & N/A \\
\hline $\begin{array}{l}\text { Feb 2008- } \\
\text { Apr } 2010\end{array}$ & $\begin{array}{l}\text { Prospective, } \\
\text { observational }\end{array}$ & 83 & $81.2(75-93)$ & N/A & $\begin{array}{l}\text { I: } 10.8 \% \text {; } \\
\text { II: } 57.8 \% \text {; } \\
\text { III: } 30.1 \% \text {; } \\
\text { IV: } 1.2 \%\end{array}$ & $\begin{array}{l}61 \\
73.5 \%\end{array}$ & $\mathrm{~N} / \mathrm{A}$ & Elective & $\begin{array}{l}\text { Colon: } \\
26.5 \% \\
\text { Rectum: } \\
73.5 \%\end{array}$ & N/A \\
\hline $\begin{array}{l}\text { Nov 2006- } \\
\text { Jun } 2008\end{array}$ & $\begin{array}{l}\text { Prospective, } \\
\text { observational }\end{array}$ & 178 & $79.6 \pm 5.7$ & $\begin{array}{l}76 \\
42.7 \%\end{array}$ & N/A & $\begin{array}{l}118 \\
66 \%\end{array}$ & N/A & Elective & $\begin{array}{l}\text { Colon: } \\
71 \% \\
\text { Rectum: } \\
29 \%\end{array}$ & $\begin{array}{l}\text { TNM stage } \\
0: 5 \% \\
\text { I: } 24 \% \text {; } \\
\text { II: } 32 \% \text {; } \\
\text { III: } 25 \% \text {; } \\
\text { IV: } 12 \% \text {; } \\
\text { Unclassified: } \\
2 \%\end{array}$ \\
\hline
\end{tabular}

ASA, American Society of Anesthesiologists. GFI, Groningen Frailty Index. *Sample derived from the same cohort.

Table 2 Prevalence of frailty and clinical outcomes in patients receiving surgery for colorectal cancer. 


\begin{tabular}{|c|c|c|c|c|c|c|c|c|c|c|}
\hline \multirow{3}{*}{$\begin{array}{l}\text { Age of } \\
\text { patients } \\
\text { (years) }\end{array}$} & \multirow{3}{*}{$\begin{array}{c}\text { Frailty } \\
\text { assessment } \\
\text { instrument }\end{array}$} & \multirow{3}{*}{$\begin{array}{l}\text { Prevalence } \\
\text { rate of frailty }\end{array}$} & \multicolumn{8}{|c|}{ Data and/ or risk estimates for clinical outcomes } \\
\hline & & & \multirow[t]{2}{*}{ LOS (days) } & \multirow[t]{2}{*}{ Readmission } & \multicolumn{3}{|c|}{ Postoperative complications } & & \multicolumn{2}{|c|}{ Mortality } \\
\hline & & & & & & Overall & Severe & & $\begin{array}{c}\leq 30- \\
\text { day/ } \\
\text { inpatient }\end{array}$ & $>30$-day \\
\hline$\geq 65$ & $\begin{array}{l}\mathrm{mFI} \text { modified } \\
\text { from frailty } \\
\text { index }\end{array}$ & $\begin{array}{l}25 \% \\
(423 / 1676)\end{array}$ & $\begin{array}{l}1.05(0.97- \\
1.15), P>0.05\end{array}$ & $\begin{array}{l}\text { OR: } 1.68 \\
\text { (95\% CI: } \\
1.20-2.36)\end{array}$ & & N/A & $\begin{array}{l}\text { OR: } 1.51 \\
(1.14-2.00\end{array}$ & & $\mathrm{N} / \mathrm{A}$ & $\mathrm{N} / \mathrm{A}$ \\
\hline$\geq 65$ & $\begin{array}{l}\text { Clinical Frailty } \\
\text { Scale }\end{array}$ & $29 \%(78 / 269)$ & $\begin{array}{l}\text { Median: frail } \\
\text { vs. non-frail: } \\
13(7-64) \text { vs. } 10 \\
(6-61), P<0.01)\end{array}$ & N/A & & N/A & $\begin{array}{l}\text { OR: } 3.42 \\
\text { (95\% CI: } \\
1.62-7.29)\end{array}$ & & $\mathrm{N} / \mathrm{A}$ & N/A \\
\hline$\geq 65$ & $\begin{array}{l}\text { Colon Cancer } \\
\text { Frailty Index } \\
\text { (CCFI) }\end{array}$ & $\begin{array}{l}34.0 \% \\
(18241 / 53652)\end{array}$ & $\begin{array}{l}\text { Median: } \\
\text { frail vs. non- } \\
\text { frail: } 8.9 \mathrm{vs} \text {. } \\
7.2, P<0.01\end{array}$ & N/A & & $\begin{array}{l}\text { OR: } 1.8(95 \% \text { CI: } \\
1.1-2.9)\end{array}$ & $\mathrm{N} / \mathrm{A}$ & & $\begin{array}{l}\text { OR: } 1.2 \\
(95 \%: \\
0.9-1.6)\end{array}$ & N/A \\
\hline$>70$ & $\begin{array}{l}\text { G8 } \leq 14+\text { ISAR-HP } \\
\geq 2\end{array}$ & $\begin{array}{l}14.6 \% \\
(20 / 137)^{\#}\end{array}$ & $\begin{array}{l}\text { Mean: frail vs. } \\
\text { non-frail: } \\
8.6 \pm 4.2 \\
\text { vs. } 8.7 \pm 7.1 \\
P>0.05 \text { ) }\end{array}$ & $\begin{array}{l}\text { OR: } 3.4 \\
(1.1-11.0)\end{array}$ & - & $\begin{array}{l}\text { OR: } 2.4 \text { (95\% CI: } \\
1.1-5.4)\end{array}$ & N/A & - & $\begin{array}{l}\text { OR: } 6.7 \\
\text { (95\% CI: } \\
1.3- \\
36.0)\end{array}$ & $\begin{array}{l}\text { OR: } 9.5 \\
(95 \% \text { C: } \\
1.9- \\
47.4)\end{array}$ \\
\hline$\geq 70$ & $\begin{array}{l}\text { Groningen } \\
\text { Frailty Index }\end{array}$ & $52.2 \%(24 / 46)$ & N/A & $\mathrm{N} / \mathrm{A}$ & & N/A & $\mathrm{N} / \mathrm{A}$ & & $\mathrm{N} / \mathrm{A}$ & $\begin{array}{l}\text { HR: } \\
2.265 \\
(95 \% \\
\text { CI: } \\
0.836- \\
6.136)\end{array}$ \\
\hline$\geq 70$ & $\begin{array}{l}\text { Comprehensive } \\
\text { Geriatric } \\
\text { Assessment }\end{array}$ & $\begin{array}{l}42.7 \% \\
(76 / 178)\end{array}$ & N/A & N/A & & N/A & $\mathrm{N} / \mathrm{A}$ & & $\mathrm{N} / \mathrm{A}$ & $\begin{array}{l}\text { HR: } 3.6 \\
\text { (95\% } \\
\text { CI: 2.3- } \\
5.5 \text { ); } \\
\text { 1-year } \\
\text { survival } \\
\text { rate: } \\
\text { frail vs. } \\
\text { non- } \\
\text { frail: } \\
80 \% \text { vs. } \\
92 \% \\
5 \text {-year } \\
\text { survival } \\
\text { rate: } \\
\text { frail vs. } \\
\text { non- } \\
\text { frail: } \\
24 \% \text { vs. } \\
66 \%\end{array}$ \\
\hline$\geq 70$ & $\begin{array}{l}\text { Groningen } \\
\text { Frailty Indicator }\end{array}$ & $\begin{array}{l}25.5 \% \\
(39 / 153)\end{array}$ & Mean: $11 \pm 0.6$ & N/A & & & N/A & & $\begin{array}{l}\text { OR: } 0.68 \\
(95 \% \text { CI: } \\
0.09- \\
5.45)\end{array}$ & N/A \\
\hline$\geq 80$ & $\begin{array}{l}\text { The Johns } \\
\text { Hopkins' } \\
\text { Adjusted Clinical } \\
\text { Groups case-mix } \\
\text { system }\end{array}$ & $\begin{array}{l}4.4 \% \\
(571 / 12979)\end{array}$ & $\begin{array}{l}\text { Median: } 9 \text { (2- } \\
165)\end{array}$ & N/A & & N/A & N/A & & $\begin{array}{l}\text { OR: } 10.4 \\
(95 \% \mathrm{CI}: \\
7.6- \\
14.2)\end{array}$ & $\begin{array}{l}\text { OR: } 8.4 \\
(95 \% \\
\text { CI: } 6.4- \\
11.1)\end{array}$ \\
\hline$\geq 75$ & $\begin{array}{l}\text { Fried frailty } \\
\text { phenotype }\end{array}$ & $27.7 \%(23 / 83)$ & N/A & N/A & - & $\begin{array}{l}\text { Overall } \\
\text { complication } \\
\text { rate: frail vs. } \\
\text { non-frail: } 47.8 \% \\
\text { vs. } 18.3 \%)\end{array}$ & N/A & - & $\mathrm{N} / \mathrm{A}$ & $\mathrm{N} / \mathrm{A}$ \\
\hline$\geq 70$ & $\begin{array}{l}\text { Comprehensive } \\
\text { Geriatric } \\
\text { Assessment }\end{array}$ & $\begin{array}{l}42.7 \% \\
(76 / 178)\end{array}$ & $\mathrm{N} / \mathrm{A}$ & $\begin{array}{l}\text { OR: } 2.80 \\
(1.06-7.41)\end{array}$ & & $\begin{array}{l}\text { Overall } \\
\text { complication } \\
\text { rate: frail } \\
\text { vs.intermediate } \\
\text { vs. fit: } 76 \% \\
\text { vs. } 48 \% \text { vs. } 48 \%\end{array}$ & $\begin{array}{l}\text { Severe } \\
\text { complication } \\
\text { rate: } 62 \% \\
\text { vs. } 36 \% \text { vs. } \\
33 \%\end{array}$ & & $\mathrm{~N} / \mathrm{A}$ & N/A \\
\hline
\end{tabular}

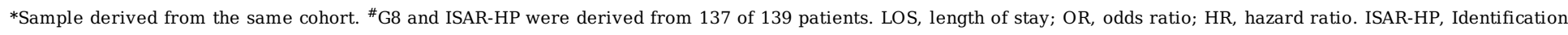
of Seniors at Risk for Hospitalised Patients. 


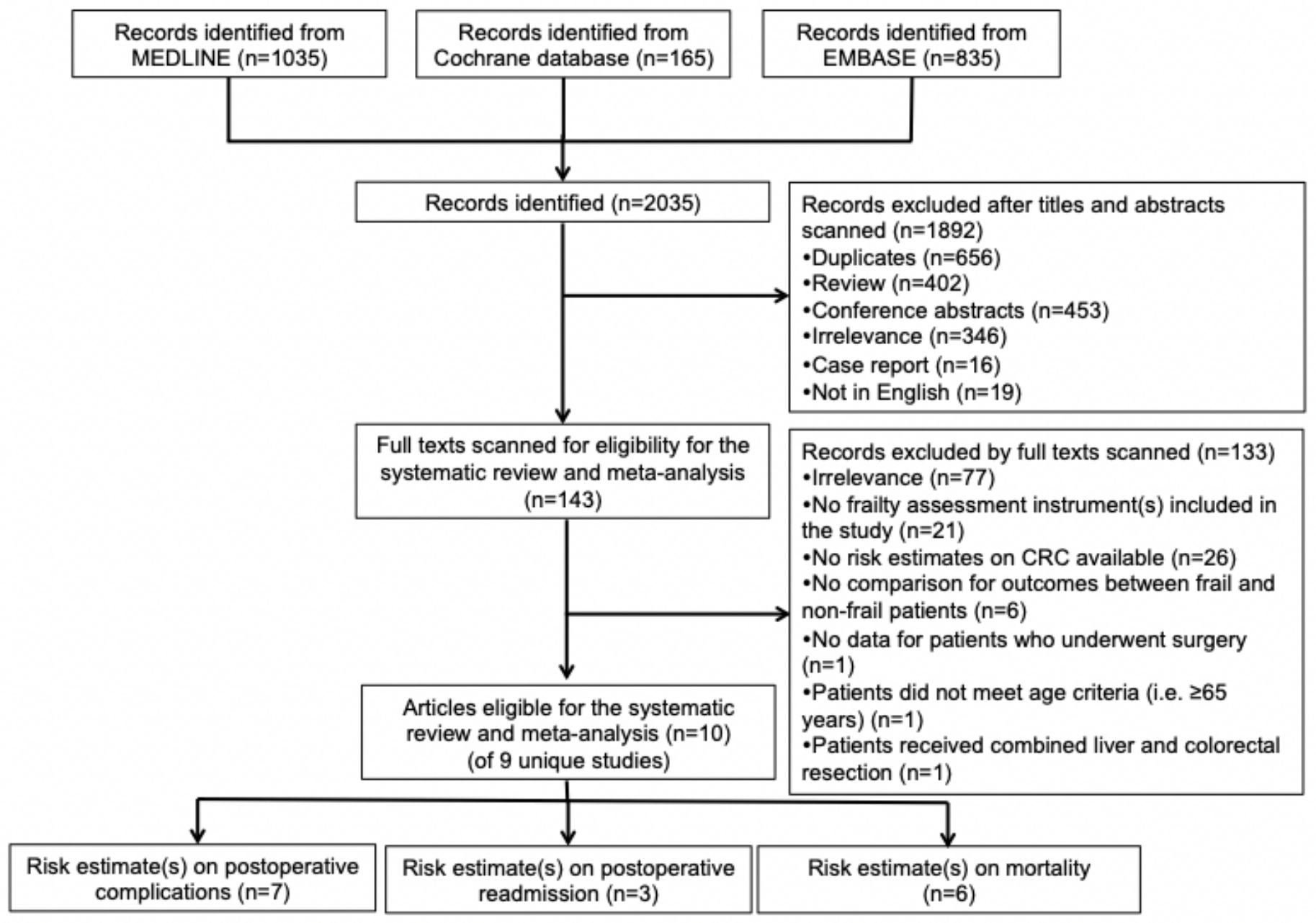

\section{Figure 1}

Flow diagram on study identification and selection. 
A

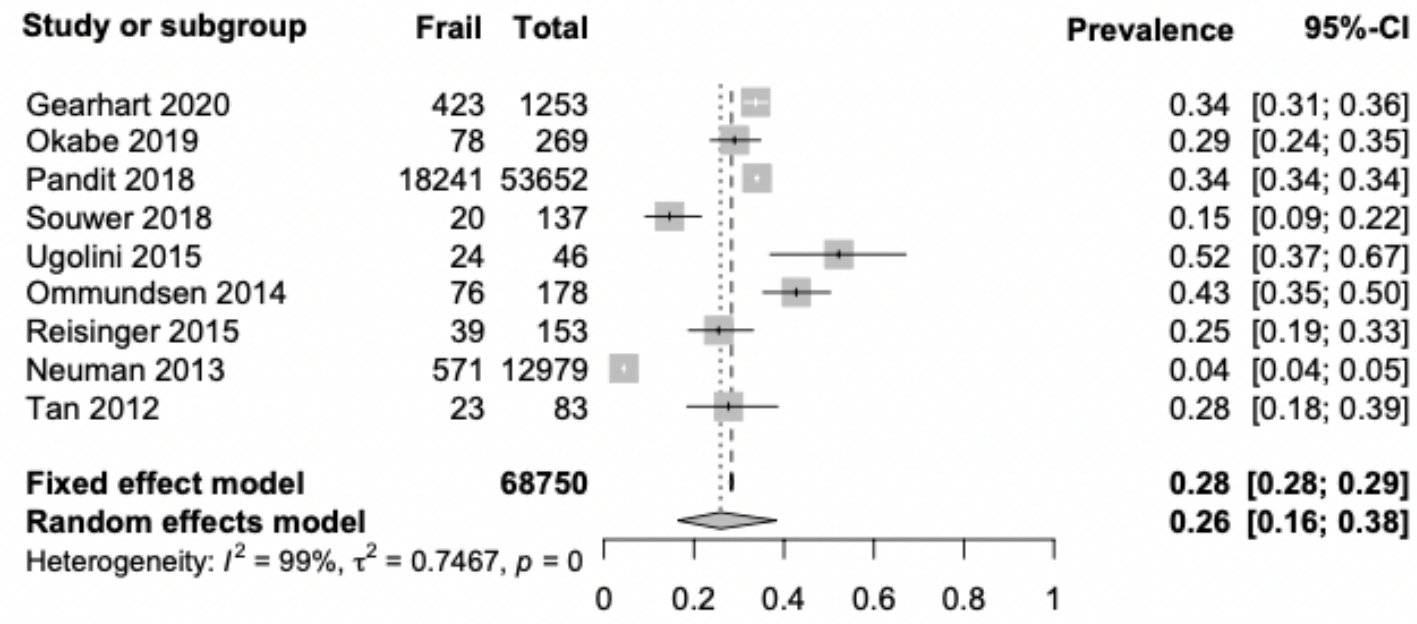

B

\begin{tabular}{|c|c|c|c|c|c|c|}
\hline Study or subgroup & Frail & Total & & & Prevalence & $95 \%-\mathrm{Cl}$ \\
\hline Okabe 2019 & 78 & 269 & $\div$ & & 0.29 & {$[0.24 ; 0.35]$} \\
\hline Pandit 2018 & 18241 & 53652 & $\vdots+$ & & 0.34 & {$[0.34 ; 0.34]$} \\
\hline Souwer 2018 & 20 & 137 & $+\vdots$ & & 0.15 & {$[0.09 ; 0.22]$} \\
\hline Ugolini 2015 & 24 & 46 & 1 & & 0.52 & {$[0.37 ; 0.67]$} \\
\hline Ommundsen 2014 & 76 & 178 & $\div$ & & 0.43 & {$[0.35 ; 0.50]$} \\
\hline Neuman 2013 & 571 & 12979 & $\vdots \vdots$ & & 0.04 & {$[0.04 ; 0.05]$} \\
\hline Tan 2012 & 23 & 83 & $\because$ & & 0.28 & {$[0.18 ; 0.39]$} \\
\hline Fixed effect model & & 67344 & $\begin{array}{r}1 \\
\end{array}$ & & \multirow{3}{*}{$\begin{array}{l}0.28 \\
0.25\end{array}$} & {$[0.28 ; 0.29]$} \\
\hline $\begin{array}{l}\text { Random effects model } \\
\text { Heterogeneity: } I^{2}=100 \%, \tau\end{array}$ & $=0.942$ & $3, p=0 \Gamma$ & 1 & $T$ & & \\
\hline & & 0 & 0.4 & 0.8 & & \\
\hline
\end{tabular}

Figure 2

Forest plot on prevalence of frailty in patients receiving surgery for CRC. (A) Overall prevalence of frailty in 9 unique studies. (B) Pooled prevalence of frailty in 7 studies focusing on elective surgery. 
A Overall postoperative complications

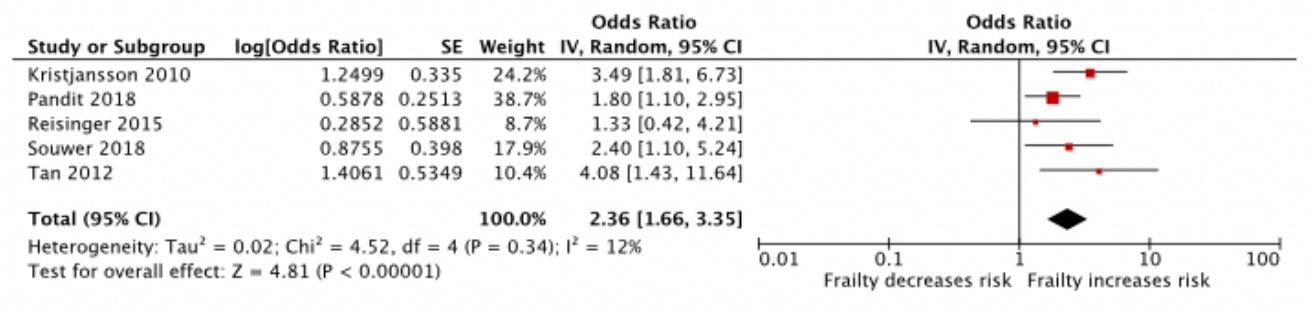

B Overall complications after elective surgery

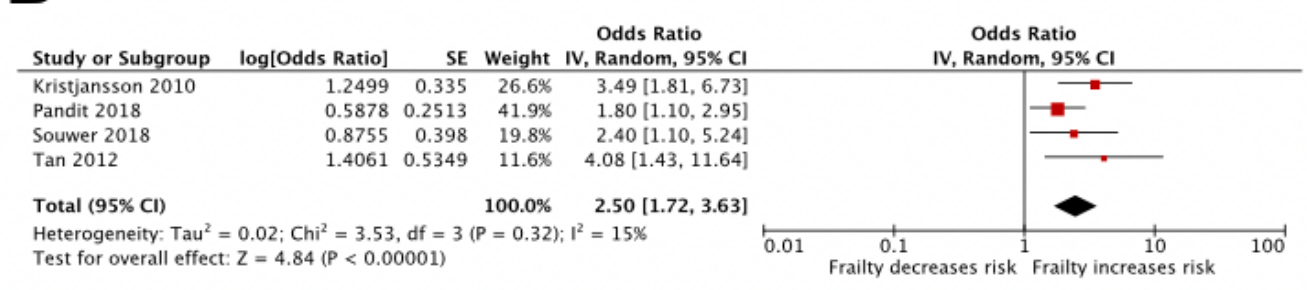

C

\section{Severe postoperative complications}

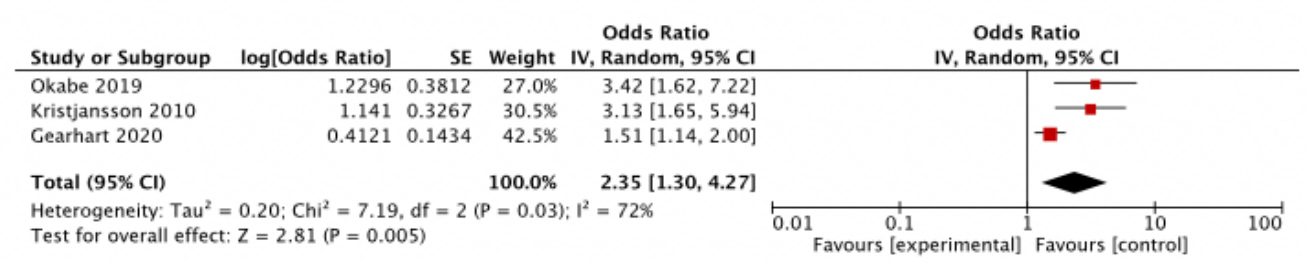

D

\section{Severe complications after elective surgery}

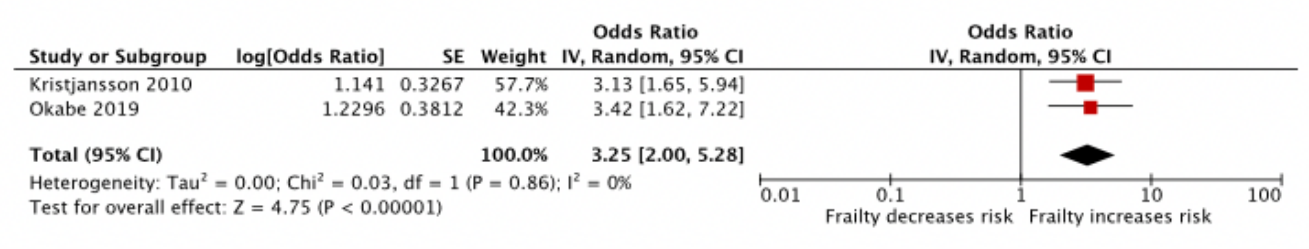

$\mathbf{E}$

Anastomotic leakage

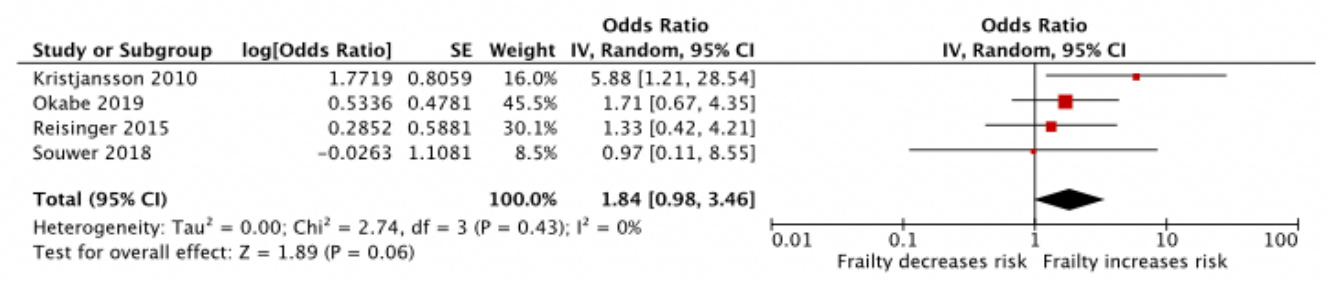

\section{Figure 3}

Effects of frailty on postoperative complications. (A) Pooled analysis on overall postoperative complications. (B) Effect of frailty on complications after elective surgery. (C) Three studies included in meta-analysis on severe complications. (D) Subanalysis on severe complications after elective surgery. (E) Summary OR on postoperative anastomotic leakage derived from 4 studies. 


\section{Postoperative readmission}

Odds Ratio

\begin{tabular}{|c|c|c|c|c|}
\hline Study or Subgroup & log[Odds Ratio] & SE & Weight & IV, Random, $95 \% \mathrm{CI}$ \\
\hline Gearhart 2020 & 0.5188 & 0.1717 & $78.5 \%$ & $1.68[1.20,2.35]$ \\
\hline Kristjansson 2010 & 1.0296 & 0.4956 & $12.3 \%$ & $2.80[1.06,7.40]$ \\
\hline Souwer 2018 & 1.2238 & 0.5758 & $9.2 \%$ & $3.40[1.10,10.51]$ \\
\hline Total $(95 \% \mathrm{Cl})$ & & & $100.0 \%$ & $1.91[1.35,2.70]$ \\
\hline
\end{tabular}

Odds Ratio IV, Random, $95 \% \mathrm{CI}$

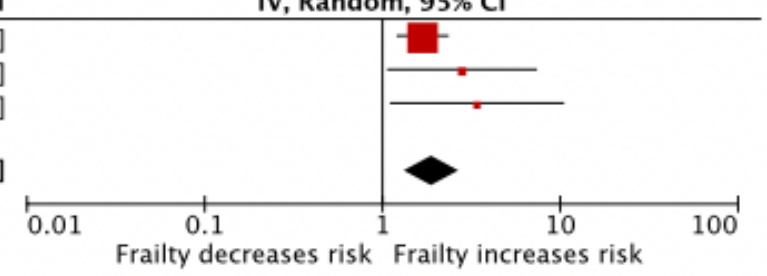

\section{Figure 4}

Forest plot for risk estimates of frailty on postoperative readmission 
Study or Subgroup log[Odds Ratio] SE Weight Odds Ratio $\begin{array}{llllll}\text { Neuman } 2013 & 2.1282 & 0.1387 & 69.4 \% & 8.40 & {[6.40,11.02]}\end{array}$ \begin{tabular}{lllll} 
Ommundsen 2014 & 1.0613 & 0.4657 & $6.2 \%$ & 2.89 \\
\hline & 0.5878 & $0.16,7.20]$
\end{tabular} $\begin{array}{lllll}\text { Pandit } 2018 & 0.5878 & 0.2513 & 21.2 \% & 1.80\end{array}[1.10,2.95]$ $\begin{array}{lllll}\text { Reisinger } 2015 & -0.3857 & 1.0318 & 1.3 \% & 0.68\end{array}[0.09,5.14]$ Souwer 2018

Total $(95 \% \mathrm{Cl})$

2.25130 .8212

$2.0 \% 9.50[1.90,47.50]$

$100.0 \% 5.52[4.40,6.92]$

Heterogeneity: $\mathrm{Chi}^{2}=35.53, \mathrm{df}=4(\mathrm{P}<0.00001) ; \mathrm{l}^{2}=89 \%$

Test for overall effect: $Z=14.77$ ( $P<0.00001)$

Odds Ratio

IV, Fixed, $95 \% \mathrm{Cl}$

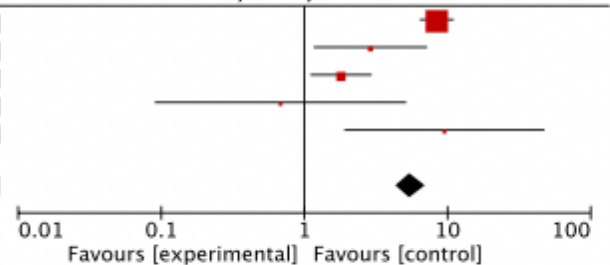

B

Mortality during 12 months after elective surgery

Study or Subgroup log[Odds Ratio] SE Weight

$\begin{array}{lllll}\text { Neuman } 2013 & 2.1282 & 0.1387 & 35.4 \% & 8.40\end{array}[6.40,11.02]$

\begin{tabular}{lllll} 
Ommundsen 2014 & 1.0613 & 0.4657 & $3.1 \%$ & 2.89 \\
\hline & {$[1.16,7.20]$}
\end{tabular}

$0.5878-0.2513-10.8 \% \quad 1.80[1.10 .2 .95]$

Souwer 2018

1.73340 .1159

Total $(95 \% \mathrm{Cl})$

$50.7 \% \quad 5.66[4.51,7.10]$

Heterogeneity: $\mathrm{Chi}^{2}=30.96, \mathrm{df}=3(\mathrm{P}<0.00001) ; \mathrm{I}^{2}=90 \%$

$100.0 \% 5.63[4.79,6.62]$

Test for overall effect: $Z=20.95$ ( $P<0.00001)$

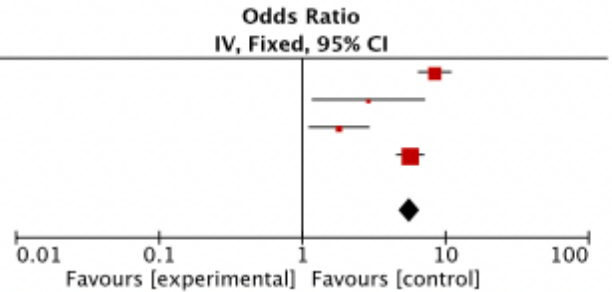

C

30-dayl inpatient mortality

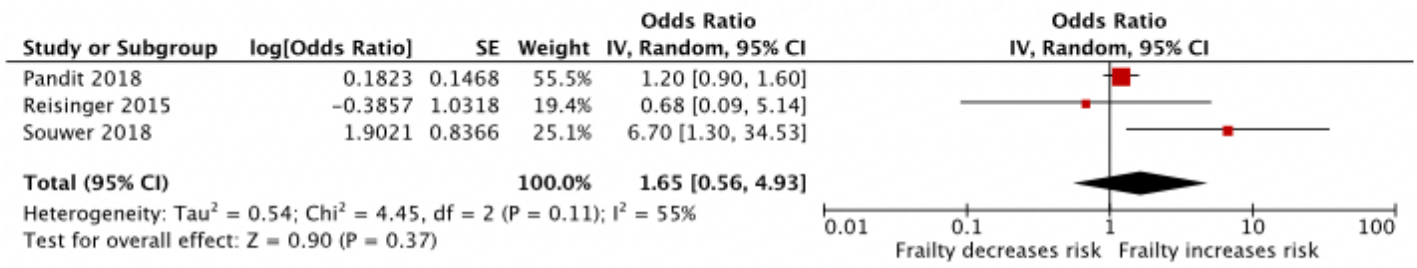

D 30-day/ inpatient mortality after elective surgery

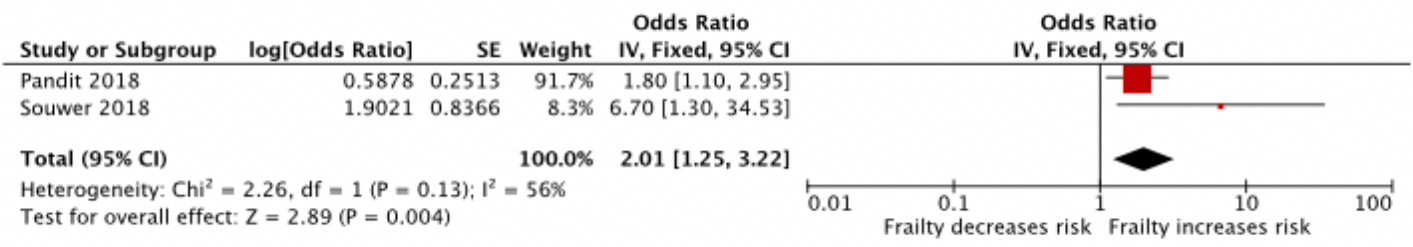

E

Mortality in time-to-event analysis

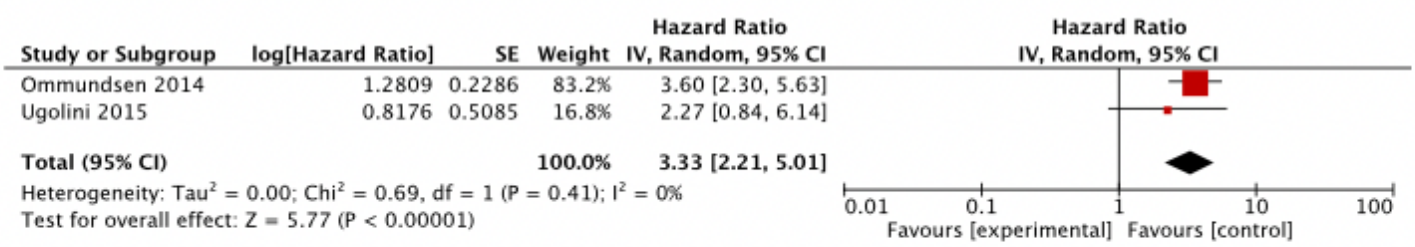

\section{Figure 5}

Forest plots on risk effects of frailty on mortality. (A) Three studies on 30-day/ inpatient postoperative mortality. (B) Subanalysis on 30-day mortality after elective surgery. (C) Risk effects of frailty on postoperative mortality during 12 months. (D) Subanalysis on mortality during 12 months after elective surgery. (E) Mortality in time-to event analysis available in 2 studies. 


\section{Supplementary Files}

This is a list of supplementary files associated with this preprint. Click to download.

- Additionalfile1TablesFigures2020jun15.docx 